Sains Malaysiana 48(8)(2019): 1707-1712

http://dx.doi.org/10.17576/jsm-2019-4808-16

\title{
The Effect of Cassava Leaves Extract on Pharmacokinetics Profile of Rutin Plasma
}

(Kesan Ekstrak Daun Ubi Kayu pada Profil Farmakokinetik Rutin Plasma)

\author{
NUGRAHANINGSIH WH*, FATIMATUZ ZAHROH, LISDIANA, ARI YUNIASTUTI \& ELY RUDYATMI
}

\section{ABSTRACT}

The leaves of cassava are used as traditional medicine, to treat ringworm, tumor, abscess, conjunctivitis, sores, headaches, rheumatism and fever diseases in several countries. Phytochemical investigations showed that flavonoids and Rutin constituents of the cassava leaves, berths the need for data as regards safety, effectiveness, toxicity and pharmacokinetics for its usage as herbal medicine. The purpose of this research was to observe pharmacokinetic parameters of Rutin in rat plasma, after oral administration of cassava leaves extract. Pharmacokinetics indicators for absorption was $\left(C_{\max }, t_{\text {max }}\right.$, and $\left.A U C_{0-24 h}\right)$, while elimination was $\left(K e\right.$ and $\left.t_{1 / 2}\right) .14$ healthy male Wistar rats were divided into 7 groups (each group with 2 rats), after which a single dose (600 $\mathrm{mg}$ ) of cassava leaves extract was given orally. Thereafter, blood samples of the wistar rats were collected and separated at different time intervals $(0 ; 0.5 ; 1 ; 2 ; 4 ; 6 ; 12 ;$ and 24 h). Using HPLCUV-VIS method, the resulting plasma was analyzed for Rutin concentration. The analysis showed Rutin concentration at $0 \mathrm{mg} / \mathrm{mL}(0 \mathrm{~h}), 0.151 \mathrm{mg} / \mathrm{mL}(0.5 \mathrm{~h}), 0.176 \mathrm{mg} / \mathrm{mL}(1 \mathrm{~h}), 0.18 \mathrm{mg} / \mathrm{mL}(2 \mathrm{~h}), 0.184 \mathrm{mg} / \mathrm{mL}(4 \mathrm{~h}), 0.163 \mathrm{mg} / \mathrm{mL}(6 \mathrm{~h})$, $0.15 \mathrm{mg} / \mathrm{mL}(12 \mathrm{~h})$ and $0.1225 \mathrm{mg} / \mathrm{mL}(24 \mathrm{~h})$. The main pharmacokinetic parameters were; $C_{\max } 0.184 \mathrm{mg} / \mathrm{mL}$ recorded $4 \mathrm{~h}\left(t_{\max }\right)$ after oral administration; $A U C_{0-24}$ was $3.583 \mathrm{mg} \mathrm{h} / \mathrm{mL}$ and $t_{1 / 2}$ was $94.54 \mathrm{~h}$. The study concluded that Rutin of cassava leaves extract, reached maximum concentration within 4 hafter oral administration and was inside in the plasma for more than $24 \mathrm{~h}$. Hence, it is recommended to consume cassava leaves extract as herbal medicine, only once a day.

Keywords: Absorption; cassava leaves extract; flavonoid; pharmacokinetics

\section{ABSTRAK}

Daun ubi kayu digunakan sebagai ubat secara tradisi untuk merawat kurap, tumor, abses, konjunktivitis, luka, sakit kepala, penyakit sendi dan demam di beberapa negara. Kajian fitokimia mendedahkan flavonoid dan rutin konstituen daun ubi kayu memberikan keperluan untuk data mengenai keselamatan, keberkesanan, ketoksikan dan farmakokinetik untuk penggunaannya sebagai ubat herba. Tujuan kajian ini adalah untuk melihat parameter farmakokinetik Rutin dalam plasma tikus, selepas pemberian oral ekstrak daun ubi kayu. Petunjuk farmakokinetik untuk penyerapan adalah $\left(C_{\text {max }}\right.$, $t_{\text {max }}$, dan $\left.A U C_{0-24 h}\right)$, manakala penghapusan adalah $\left(\right.$ Ke dan $\left.t_{1 / 2}\right)$. Sejumlah 14 tikus Wistar jantan yang sihat dibahagikan kepada 7 kumpulan (setiap kumpulan dengan 2 tikus), dan seterusnya satu dos (600 mg) ekstrak daun ubi kayu diberikan secara oral. Sampel darah tikus wistar dikumpulkan dan dipisahkan pada jarak masa berlainan $(0 ; 0.5 ; 1 ; 2 ; 4 ; 6 ; 12$; dan 24 jam). Menggunakan kaedah HPLC-UV-VIS, plasma yang dihasilkan dianalisis untuk kepekatan rutin. Analisis itu menunjukkan kepekatan Rutin pada $0 \mathrm{mg} / \mathrm{mL}(0 \mathrm{jam}), 0.151 \mathrm{mg} / \mathrm{mL}(0.5 \mathrm{jam}), 0.176 \mathrm{mg} / \mathrm{mL}(1 \mathrm{jam}), 0.18 \mathrm{mg} / \mathrm{mL}(2 \mathrm{jam})$, $0.184 \mathrm{mg} / \mathrm{mL}$ (4 jam), $0.163 \mathrm{mg} / \mathrm{mL}$ (6 jam), $0.15 \mathrm{mg} / \mathrm{mL}$ (12 jam) dan $0.1225 \mathrm{mg} / \mathrm{mL}$ (24 jam). Parameter farmakokinetik utama adalah; $C_{\max } 0.184 \mathrm{mg} / \mathrm{mL}$ mencatatkan $4 \mathrm{jam}\left(t_{\max }\right)$ selepas pemberian oral; $A \mathrm{UC}_{0-24}$ adalah $3.583 \mathrm{mg} \mathrm{jam} / \mathrm{mL}$ dan $t_{1 / 2}$ adalah 94.54 jam. Kajian itu menyimpulkan bahawa Rutin daun daun ubi kayu, mencapai kepekatan maksimum dalam masa 4 jam selepas pengambilan secara oral dan berada di dalam plasma selama lebih dari 24 jam. Oleh itu, disarankan untuk mengambil ekstrak daun ubi kayu sebagai ubat herba, hanya sekali sehari.

Kata kunci: Ekstrak daun ubi kayu; farmakokinetik; flavonoid; penyerapan

\section{INTRODUCTION}

Cassava is one of the shrubs that belong to the family Euphorbiaceae, originated from South America and continues to spread to Indonesia and across Asia. People consume the cassava leaf as vegetable and herb medicine, as it contains mineral and electrolyte such as $\mathrm{Na}, \mathrm{K}, \mathrm{Fe}$, $\mathrm{Zn}, \mathrm{al}, \mathrm{Rb}, \mathrm{Ba}$, and $\mathrm{Cu}$ (Nugrahaningsih et al. 2017). Phytochemical compounds of the cassava leaves extract were flavonoids, antocyanin and phenol (Suresh et al. 2011).
Cassava leaves are traditionally used to treat fever, rheumatism, headaches, and hemorrhoids. Its herbal efficacy is also renowned in Nigeria, for its potential to protect people from ringworm, tumor, abscess, conjunctivitis, and sores (Miladiyah 2011). Chloroform extract of this cassava leaves, also combats bacterial activity of V.cholera, Shigella flexneri, S. thyphi and P. auruginosa (Zakaria 2006). This herbal leaf possesses anti-bacterial, anti-inflammatory, hepatoprotective, anti-cancer and antiviral agents' properties (Kumar \& Abhay 2013). Cassava 
leaves in the form of aqueous extract, methanol and ethanol can also inhibit LDL oxidation, chelate cupric ions and reduce ferric ions. These biological activities are attributed to the presence of several phytochemical compounds, in the cassava leaves extract such as anthocyanins, polyphenol compounds and flavonoids (Suresh et al. 2011; Wong et al. 2006). Rutin, the flavonoid of Cassava leaf, is extracted by the HPLC method, which can reduce cholesterol levels through its ability to inhibit the formation of endogenous cholesterol (Nik Hassan et al. 2014; Tzumbu et al. 2011;). In contrast, there has been evidence of large-amount consumption of Cassava leaves, causing goiters by decreasing iodine absorption (Osman et al. 1993).

The advantages and disadvantages of Cassava leaves suggest the need of safety and efficacy data as regards its use and consumption. Different compounds and substances, experience the process of absorption, distribution, metabolism and excretion (ADME) differentially, when administered orally. The flavonoid compounds from the cassava leaves extracts, undergo extensive intestinal metabolism after ingestion. Metabolites from this flavonoid are transported to the liver, via the hepatic portal vein, undergoing further metabolism. The liver metabolites are transported to targeted cells and tissues through the blood, excreted through the bile after enterohepatic recirculation, or eliminated via urine or feces (Thilakarathna \& Rupasinghe 2013). This metabolite from the flavonoid, binds with the protein plasma and in some cases roams free in the plasma (Setyawati 2015).

The presence of a compound in a plasma, tissue or organ, provides information to determine the drug of choice, therapeutic management and residual analysis (Shargel et al. 2012). There is a dire need for pharmacokinetic data as regards to extraction of cassava leaves as a herb, hence this study was targeted at understanding the bioavailability of the Rutin of the cassava leaves extract after oral administration.

\section{MATERIALS AND METHODS}

\section{EXPERIMENTAL ANIMAL}

Fourteen (14) healthy male Wistar rats weighing between 150-200 g, were taken from Laboratory of Biology, Faculty of Mathematics and Natural Sciences, Universitas Negeri Semarang. The rats were divided into 7 groups and caged based on those groups, they were also fed with food and water ad libitum, for an acclimatization period of 5 days (Nessa et al. 2013).

\section{EXPERIMENTAL STUDY}

The Wistar rats were placed on $12 \mathrm{~h}$ fasting, receiving only water ad libitum. After which an oral single dose $(600 \mathrm{mg})$ of cassava leaves extract, was administered through their drinking water. Blood sample was taken from the orbital vein $(1.5 \mathrm{~mL})$ and were collected in EDTA tube from each group, at time intervals of $0,0.5,1,2,4,6,12$ and $24 \mathrm{~h}$ after oral administration. The blood samples were immediately centrifuged at $3000 \mathrm{rpm}$ for $5 \mathrm{~min}$, before the level of Rutin plasma was analyzed by HPLC (Kanimozhi 2016; Nessa et al. 2013).

\section{DETERMINATION OF RUTIN IN PLASMA}

Rutin of cassava leaves extract was determined by a method based on Kanimozhi (2016) with some modifications. The extraction procedure was carried out with measuring glass tubes $(10 \mathrm{~mL})$, filled with Plasma aliquot $(0.1 \mathrm{~mL})$ and shaken with 1.0 methanol for 2 min before filtration by membrane filter $(45 \mu \mathrm{m})$. Afterwards, the methanol extract was transferred to dry tube, while a $20 \mu \mathrm{L}$ filtrate of each sample was injected into the chromatographic system.

\section{CHROMATOGRAPHIC CONDITIONS}

The profile of Rutin in rat plasma was analyzed by HPLC with a UV detector, while chromatographic separation was achieved through a reverse phase $\mathrm{C} 18$ column (150 $\mathrm{mm}$ and $4.6 \mathrm{~mm}, 5 \mu \mathrm{m}$ pore size). The mobile phase used consisted of eluent A acetonitrile (27\%) and eluent B (methanol (8\%): water $(87 \%)$ : acetic acid (5\%) $(73 \%)$, pH adjusted to 3.64 with acetic acid with a motion phase flow of $0.5 \mathrm{~mL} / \mathrm{min}$, a column temperature of $25^{\circ} \mathrm{C}$ and a wavelength of 347 $\mathrm{nm}$. The experiment was performed two times, hence the mean was used for calculations (Kanimozhi 2016 with modification).

\section{CALIBRATION CURVES}

The calibration curves were prepared by spiking standard solution of Rutin (Merck), into methanol until concentration of $12.5,25,50,100$, and 200 ppm was achieved. After which the Rutin solution was injected into the HPLC system for analysis, with the resulting calibration curve shown in Figure 1. From the curve results, an equation was derived to determine Rutin concentration of cassava leaves extract in the plasma.

\section{DATA ANALYSIS}

Rutin concentration in the blood plasma was analyzed descriptively, using Microsoft Excel to analyze the equation of the calibration curve. The maximum plasma concentration $\mathrm{C}_{\max }$ and the time taken to achieve $\mathrm{C}_{\max }\left(\mathrm{t}_{\max }\right)$, were determined directly from the data. Also, $\mathrm{AUC}_{0-24 \mathrm{~h}}$ was calculated using the linear trapezoidal rule, while the apparent terminal elimination half-life $\left(\mathrm{t}_{1 / 2}\right)$ was determined using $0.693 / \mathrm{Ke}$ (Ke been the slope of the linear regression of the plasma metabolite concentration) (Mullen et al. 2009).

\section{RESULTS AND DISCUSSION}

\section{RESULTS}

Equation $y=b x+a$, was used for the linear regression analysis, with results showing calibration curve of Rutin, 


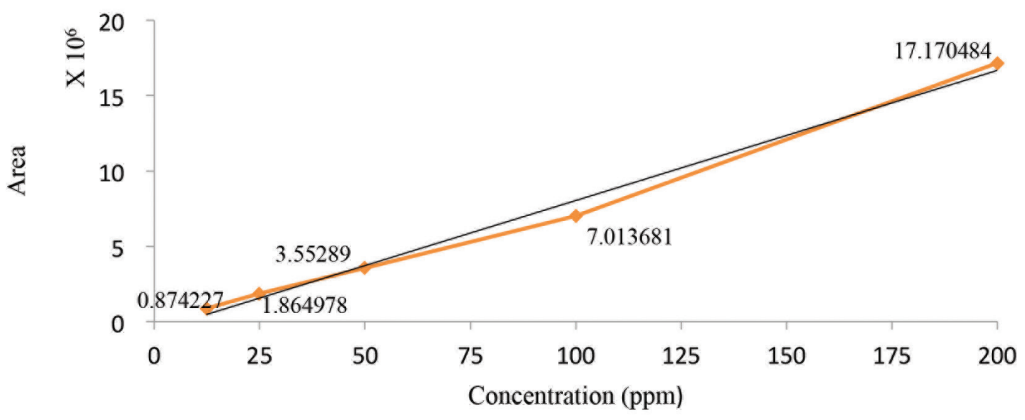

FIGURE 1. The Calibration curve of Rutin

was linear in the range concentration of $12.5,25,50$, 100 , and $200 \mathrm{ppm}$. The equation was determined using the Microsoft excel platform, whilst the equation was set at $y=86398$ and $x=600586$. The value of $\mathbf{x}$ was Rutin concentration, while $\mathbf{y}$ was the area under the peak of Rutin chromatogram (equation curve as shown in Figure 1). The equation curve of Figure 1 was used to calculate flavonoid concentrations, in the plasma marked with Rutin.

The flavonoids Rutin were easily absorbed and readily detected in rat plasma, after oral administration of the cassava leaves extract to the rat. The mean blood concentration versus time curve of the flavonoids, were presented in Figure 2. Maximum plasma concentration $\left(\mathrm{C}_{\text {max }}\right)$ and the time taken to achieve the maximum concentration $\left(\mathrm{T}_{\max }\right)$, were obtained through visual inspection of the plasma concentration versus time curve. The Area Under concentration Curve (AUC) from 0 to 24 , was determined by the linear trapezoidal rule, while elimination half-life $\left(t_{1 / 2}\right)$ was calculated by $0.693 / \mathrm{Ke}$. Mean and S.D were determined for the pharmacokinetic parameters and were further were tabulated in Table 1.
After administration of cassava leaves extract, results showed peak concentration $\left(\mathrm{C}_{\max }\right)$ was $(0.184 \pm 0.022 \mathrm{mg} /$ $\mathrm{mL})$, while $\mathrm{T}_{\max }$ was $(4 \mathrm{~h})$. The value of AUC $\mathrm{t}_{0}-\mathrm{t}_{24}$ was $3.583 \pm 0.58 \mathrm{mg} . \mathrm{h} / \mathrm{mL}$, with $\mathrm{t}_{1 / 2}$ elimination at $94.54 \mathrm{~h}$ after oral administration of cassava leaves extract.

\section{DISCUSSION}

Flavonoid was present in the rat plasma, but in conjugated or metabolites form. The metabolism of flavonoid involved two important organs; the liver, where biotransformation enzymes coverts flavonoid or its metabolites into conjugated forms such as glucoronides or sulphates (Richelle et al. 1999), and the colon, where microorganisms degrade unabsorbed flavonoids (Rowland \& Tozer 1995). The extraction procedure of flavonoids from rat plasma was simple and rapid.

This study showed that the levels of Rutin plasma, appeared the kinetic of flavonoid from $600 \mathrm{mg} / \mathrm{mL}$ cassava leaves extract, but not its metabolites. Analysis of the compound (flavonoid) in the plasma, provided

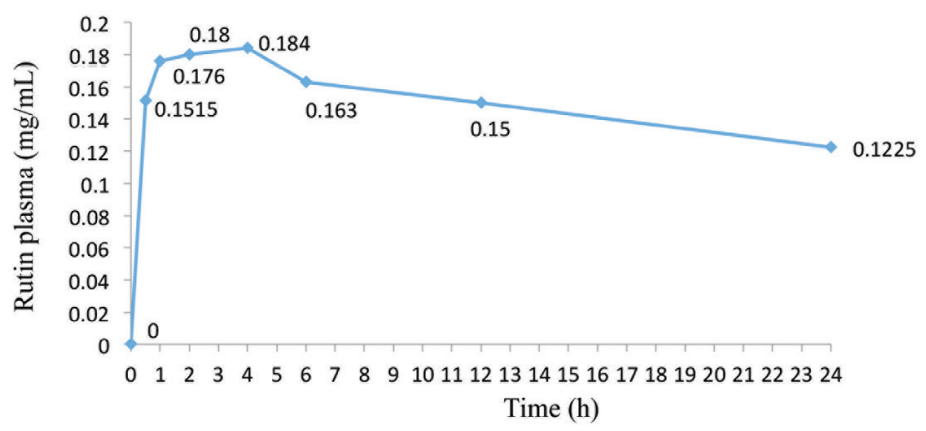

FIGURE 2. Plasma concentration time profile for Rutin in rats following oral administration of $600 \mathrm{mg}$ of cassava leaves extract

TABLE 1. Pharmacokinetic parameters of Rutin plasma after $600 \mathrm{mg}$ oral administration of cassava leaves extract

\begin{tabular}{lcc}
\hline Pharmacokinetic parameters & Values & Units \\
\hline $\mathrm{C}_{\max }$ & $0.184 \pm 0.022$ & $\mathrm{mg} / \mathrm{mL}$ \\
$\mathrm{T}_{\max }$ & 4 & $\mathrm{~h}$ \\
AUC (Area Under Curve) & $3.583 \pm 0.58$ & $\mathrm{mg} \mathrm{h} / \mathrm{mL}$ \\
$\mathrm{t}_{1 / 2}$ & 94.54 & $\mathrm{~h}$ \\
\hline
\end{tabular}


useful information in determining dosage and the timing of administration, for its appropriate and safe use as a drug. The plasma concentration curve represents the net results of two opposite processes; absorption vs elimination (Richelle et al. 1999). This time-concentration curve signifies the potential for enterohepatic receptor flavonoids, as Rutin was present in high amounts in cassava leaves extract, hence it was used as a bio-marker for the absorption of cassava leaves extract.

During the post-absorptive period, whilst absorption in the small intestine was declining (due to transit of digest and dilution of remaining digest by endogenous material), flavonol absorption was however taking place in the large intestine (Kanimozhi 2016). After consumption of a single dose $(600 \mathrm{mg})$ of cassava leaves extract, flavonoid was rapidly absorbed, reaching maximum plasma concentration $\left(\mathrm{C}_{\max }\right)$ within $4 \mathrm{~h}$ after oral administration. This result suggested that flavonoid was quickly metabolized by the intestinal enzymes and strongly bound to albumin (Manach et al. 1999), which might delay their preferential movement to the bile for excretion (Jain et al. 2013). The $\mathrm{C}_{\max }$ and $\mathrm{t}_{\max }$ values suggests circulation of metabolites or conjugated flavonoid, as its extravascular administration was needed to consider these parameters. Hence, the slow drug absorption was characterized by a reduction in $\mathrm{C}_{\text {max }}$ and increase of $\mathrm{T}_{\text {max. }}$ (Rowe 2012). These parameters $\left(\mathrm{C}_{\max }\right.$ and $\mathrm{t}_{\max }$ ) are important, in the development and formulation of any new drug or formulation.

The curve in Figure 2 illustrated the slow and steady decrease of Rutin levels after $t_{\text {max }}$ was reached, indicating that the flavonoids of cassava leaves extract was still present in the plasma at sufficient levels. The value of Ke (elimination rate) obtained was smaller $\left(0.00733 \mathrm{hr}^{-1}\right)$ than the value of $\mathrm{Ka}$ (absorption rate) $\left(0.01686 \mathrm{hr}^{-1}\right)$, indicating that the process of elimination was slow compared to absorption which occurred quickly. The value of Ka and Ke was a proportional supporting parameter, because if $\mathrm{Ka}$ 's value was greater than $\mathrm{Ke}$, the absorption rate will be faster than the elimination rate and vice versa. Slow elimination implicated that no repetition was required, in the application of cassava leaves extract in one day.

The peak concentration value $(0.184 \mathrm{mg} / \mathrm{mL}) \mathrm{did}$ not decline by half, for up to $24 \mathrm{~h}(0.125 \mathrm{mg} / \mathrm{mL})$, hence the value of $t_{1 / 2}$ over $24 \mathrm{~h}$ was $94.54 \mathrm{~h}$. The total absorption of Rutin, as determined from the area under the plasma concentration-time curve (AUC) was 3.583 $\mathrm{mg} . \mathrm{h} / \mathrm{mL}\left(\mathrm{AUC}_{0-24 \mathrm{~h}}\right)$. The AUC is a measurable extent of drug bioavailability, reflecting the total amount of active drug that reaches systemic circulation (Shargel et al. 2012). The AUC values were affected by $C_{\max }$ and $t_{1 / 2}$ concentration, where the higher concentration for each time, the higher value of AUC (Tao et al. 2015). The halflife indicates the time it takes for the drug to reach half concentration of its original content (Setiya et al. 2009), furthermore describes the elimination of compounds in the plasma, before undergoing a process of distribution to a liver-like tissue. This $\mathrm{t}_{1 / 2}$ duration corresponds to the Rutin concentrations curve in the plasma, against time which indicates a decrease point relative to the axis point. Therefore, extra time was allotted after $24 \mathrm{~h}$ to monitor the flavonoids concentration halve or migrate from the plasma to the target tissue. Noticeably, the difference in half-life between individuals or animals is caused by absorption, metabolism and excretion factors.

The flavonoids were conjugated to O-glucuronides, sulphate ester, o-methyl esters and aglycones in the small intestine, liver and colon before its hydrolyzation. The conjugated flavonoids are present in the plasma (Landete 2012) after oral administration, after crossing the intestinal walls to undergo further catabolism. The first conjugation of flavonoids occurs in the small intestine, after which the resulting metabolites are transported to the liver via hepatic portal vein. This metabolites is transported to targeted cells and tissues, excreted to the bile for enterohepatic re-circulation, or eliminated via urine and/or feces (Thilakarathna \& Rupasinghe 2013). Compounds not absorbed by the intestines will reach the colon, for subjection to structural modification by the colon microfolia's (Del Rio et al. 2010). The aglycones can also further be catabolized to low molecular weight compounds, that can readily be absorbed (Thilakarathna \& Rupasinghe 2013).

Enterohepatic recirculation of metabolites flavonoid, also indicates reabsorption by the colon. This process further resulting to the second rise of level, might be due to the interaction of colonic bacteria on flavonoid glycosides, bound to the food matrix such as dietary fiber. The released glycosides of flavonoid may be hydrolyzed in colon (Aheme \& O'Brien 2002), as bacterial glucosides cleave the flavonoid ring, resulting in ring fission products such as hydroxyl phenylacetic acid (Aheme \& O'Brien 2002; Mullen et al. 2008). The different absorption phase among subject or object may have been as a result of carriermediated transport processes, physiological differences such as pH changes along the intestinal tract and distinct transit time (Lee \& Alyson 2012).

Flavonoids structure also affects the absorption process, as flavonoid aglycone is easily absorbed by the intestines, compared to flavonoids glycosides that must be converted into aglikon before absorption (Hollman 2004). Flavonoids were found in blood plasma, but in conjugate forms of glucuronide and glucuronide/sulphate (Graefe et al. 2001; Piskula \& Junji 1998). Absorption of flavonoids cassava leaves extract orally is relatively quick, compared to flavonoids that are administered in their pure form. Similarly, Kanimozhi (2016) study showed that 50 $\mathrm{mg} / \mathrm{kg}$ of flavonoids administered orally, reached peak time after $6 \mathrm{~h}$. Oral administration of Rutin and quercetin, also appears as glucuronide and quarcetine sulfate in the plasma after $5 \mathrm{~min}$, indicating rapid absorption compared to cassava leaf extract (Yang et al. 2005). Giving tea buckling, time to attain peak concentrations was however achieved almost par, to oral administration of cassava leaves extract at $4.3 \pm 1.8 \mathrm{~h}$. However, pure routine delivery achieved a longer peak time of $7.0 \pm 2.9$ h (Graefe et al. 2001), although its absorption was not 
rapid compared to the oral administration of the cassava leaves extract.

The absorption between experimental animal and individuals, varies depending on the given dosage form, anatomy and the physiology of the absorption site. Flavonoid absorption process is influenced by several things such as physicochemical properties including molecular size, shape, lipopholicity, solubility and pKa (Kumar \& Abhay 2013). In this study, dietary factors were minimized through the $12 \mathrm{~h}$ fasting placed on the rats, giving only drinking water, as food also affects absorption rate. Flavonoids (such as quarcetin and Rutin) when administered through intravenous pathways cannot be detected routinely (Graefe et al. 2001). However, oral administration may decrease bioavailability due to imperfect absorption or drug interactions with other substances (Shargel et al. 2012). The dosage given was in liquid form, for easy absorption into the body, as molecular factors including differences in activity and synthesis of different enzymes are involved in biotransformation (Meibohm et al. 2002). The study was limited to rats and might significantly differ in humans, due to physiological and anatomical variations. Hence, future research should be focused on the exact pharmacokinetic parameters in human.

\section{CONCLUSION}

The flavonoid Rutin of cassava leaves extract absorbed into the small intestine, reaches the plasma within $30 \mathrm{~min}$ after oral administration. Furthermore, the high value of Rutin in the plasma indicates the long half-life of the extract and its slow elimination. Additionally, general variations in pharmacokinetic parameters can be caused by physiological factors such as differences in body weight, body composition, gastric motility, and associated molecular factors.

\section{ACKNOWLEDGEMENTS}

The authors express the gratitude to thank Professor Fahrul Zaman Huyop (Ph.D) from the Faculty of Biosciences and Medical Engineering (FBME), Universiti Teknologi Malaysia.

\section{REFERENCES}

Aheme, S.A. \& O'Brien, N.M. 2002. Dietary flavonols: Chemistry, food content, and metabolism. Nutrition 18: 75-81.

Del Rio, D., Calani, L., Scazzina, F., Jechiu, L., Cordero, C. \& Brighenti, F. 2010. Bioavailability of catechins from readyto-drink tea. Nutrition 26: 528-533.

Graefe, U.E., Wittig, J., Mueller, S., Riethling, A.K., Uehleke, B., Drewelow, B., Pforte, A., Jacobasch, K., Derendorf, H. $\&$ Velt, M. 2001. Pharmacokinetics and bioavaibility of quarcetin glycosides in humans. Jurnal Clin. Pharmacol. 41: 492-499.

Hollman, P.C.H. 2004. Absorption, bioavailability, and metabolism of flavonoids. Pharmaceutical Biology 42: 74-83.
Jain, A.K., Thanki, K. \& Jain, S. 2013. Coencapsulation of tamoxifen and quarcetin in polymeric nanoparticles: Implications on oral bioavailability, anti-tumor efficacy and drug-induced toxicity. Mol. Pharm. 10: 3459-3474.

Kanimozhi, S. 2016. Oral administration of a flavonoid quarcetin in rat plasma on bioavaibility study analysis by HPLC. Life Science Archives 2(2): 508-513.

Kumar, S. \& Abhay K.P. 2013. Chemistry and biological activities of flavonoid: An review. The Scientific World Journal 2013 162750 .

Landete, J.M. 2012. Funtions, bioavaibility, metabolism, and health. Crit. Rev. Food Sci. Nutr. 52: 276-948.

Lee, J. \& Alyson, E.M. 2012. Pharmacokinetics of quarcetin absorption from apples and onions in healthy humas. Journal of Agrcultural and Food Chemistry 60: 3874-3881.

Manach, C., Texier, O., Morand, C., Crespy, V., Régérat, F., Demigné., C. \& Rémésy, C. 1999. Comparison of the bioavailability of quarcetin and catechin in rats. Free Radic. Boil Med. 27: 1259-1266.

Meibohm, B., Beierle, I. \& Derendorf, H. 2002. How important are gender differences in pharmacokinetics. Clin. Pharmacokinetic 41: 329-342.

Miladiyah, I., Ferdiyanto, D. \& Sufi, D. 2011. Analgesic activity of ethanolic extract of manihot esculenta crantz leave in mice. Universa Medicina 30(1): 3-10.

Mullen, W., Gina, B., Jennifer, L., Donovan, C.A.E., Mauro, S. \& Michael, E.J.L. 2009. Milk decreases urinary excretion but not plasma pharmacokinetica of cocoa flavan-3-O1 metabolites in humans. Am. J. Clin. Nutr. 89: 1784-1791.

Mullen, W., Rouanet, J., Auger, C., Tessie, D.P., Caldwell, S.T., Hartley, R.C., Lean, M.E.J., Edwards, C.A. \& Crozier, A. 2008. Bioavailibility of [2-14C] quercetin-4'-glucoside in rats. J. Agric. Food Chem. 56: 12127-12137.

Nessa, F., Zhari, N., Nornisah, M. \& Sundram, K. 2013. Simultaneous quantification of flavonoids in blood plasma by a high-performance liquid chromatography method after oral administration of Blumea balsamifera leaf extract in rats. Pak. J. Pharm. Sci. 26(2): 375-381.

Nik Hassan, M.K., Ali, R.M., Hj Amom, Z., Shah, M.Z., Arshad, M.S.M., Kadir, K.K.A. \& Kamarazaman, I.S. 2014. Effect of apigenin, berberine and rutin on cholesterol metabolism in Hep G2 cancer cell. Sains Malaysiana 43(4): 559-566.

Nugrahaningsih, W.H., Lisdiana \& Purwantoyo, E. 2017. Mineral and electrolyte analysis of Manihot utilissima and Carica papaya leaves: A prospect of anti hypotension agent. International Conference on Herbal and Traditional Medicine 2017: 121-126

Osman, B.A., Ng, M.L., Bakar, A.A. \& Khafid, B.A. 1993. The effect of Cassava leave intake on thyroid hormone and urinary iodine. East Afr. Med. J. 70(5): 314-315.

Piskula, K.M. \& Junji, T. 1998. Quarcetin's solubility affects its accumulation oral administration. J. Agric. Food Chem. 46: 4313-4317.

Richelle, M., Tavazzi, I., Enslen, M. \& Offord, E.A. 1999. Plasma kinetics in man of epicatechin from black chocolate. European Journal of Clinical Nutrition 53: 22-26.

Rowe, P. 2012. Pharmacokinetics. Ventus Publishing Aps; download free ebook at bookboon.com.

Rowland, R.V. \& Tozer, N.T. 1995. Clinical Pharmacokinetics, Concepts and Applications. $3^{\text {rd }}$ ed. Philadhelphia: Lea \& Febiger Inc.

Setiya, B.A., Toetik, A. \& Khoirotin, N. 2009. Pengaruh sirkadian pada farmakokinetik sulfametoksazol oral dengan data darah kelinci. Majalah Farmasi Airlangga 7(1): 19-23. 
Setyawati, F.N. 2015. Dasar-Dasar Farmakologi Keperawatan. Yogyakarta: Binafsi Publisher.

Shargel, L., Wu-Pong, S. \& Andrew, B.C. 2012. Applied Biopharmaceutics and Pharmacokinetics. $7^{\text {th }}$ ed. USA: Company, Inc.

Suresh, R., Saravanakumar, M. \& Sugayanadevi, P. 2011. Anthocyanins from Indian cassava (Manihot esculenta Crantz.) and its antioxidant properties. IJPSR 2(7): 18191828.

Tsumbu, C.N., Deby-Dupont, G., Tits, M., Angenot, L., Franck, T., Serteyu, D. \& Monithys-Mickalad, A. 2011. Antioxidant and antiradical activities of Manihot esculenta Crantz (Euphorbiaceae) leaves and other selected tropical green vegetables investigated on lipoperoxidation and phorbol-12myristate-13-acetate (PMA) activated monocytes. Nutrients 3(9): 818-838

Thailakaratha, H.S. \& Vasantha Rupasinghe, H.P. 2013. Flavonoid bioavaibility and attempts of bioavaibility enhancement. Nutrients 5: 3367-3387.

Wong, S.P., Leong, L.P. \& Koh, J.H.W. 2006. Antioxidant activities of aqueous extract of selected plants. Food Chem. 99: 775-783.

Yang, C.Y., Su-Lan, H., Kuo-Ching, W., Shiuan-Pey, L., ShangYuan, T., Yu-Chi, H. \& Pei-Dawn, L.C. 2005. Bioavailavility and metabolic pharmacokinetics of rutin and quarcetin in rats. Journal of Food and Drug Analysis 13(3): 244-250.
Zakaria, Z.A. 2006. Antimicrobial activity of Manihot esculenta leaf extract. International Journal of Pharmacology 2(2): 218-220.

Nugrahaningsih WH*, Lisdiana, Ari Yuniastuti \& Ely Rudyatmi Department of Biology

Faculty of Mathematics and Natural Sciences

Universitas Negeri Semarang

50229 Semarang, Jawa Tengah

Indonesia

Fatimatuz Zahroh

Student of Graduate Program

Department of Biology

Faculty of Mathematics and Natural Sciences

Universitas Negeri Semarang, 50229 Semarang

Jawa Tengah, Indonesia

*Corresponding author; email: nugrahaningsihwh@mail.unnes. ac.id

Received: 18 September 2018

Accepted: 24 May 2019 